\title{
A Semiotic Study on Print Advertisements of Luxury Perfume Brands for Women
}

\author{
Yuping Zhang ${ }^{1}$ \\ ${ }^{1}$ Zhongkai University of Agriculture and Engineering, Guangzhou, China \\ Correspondence: Yuping Zhang, Zhongkai University of Agriculture and Engineering, Guangzhou, China.
}

Received: January 10, 2019

Accepted: January 18, 2019 Online Published: January 18, 2019

doi:10.20849/ajsss.v4i1.540

URL: https://doi.org/10.20849/ajsss.v4i1.540

\begin{abstract}
Semiotics is an indispensable theory of decoding images in modern times. In this paper, I will focus on three important scholars in the semiotics study area who are Saussure, Peirce and Barthes, their theories are extremely important and useful for helping us analyse advertisements. In this case, I use their theories to analyse two luxury perfume advertisements which is Dior J'adore and Burberry London, and can understand the meanings and structures of the advertisements by the theory of semiotics. These semiotic theories explain symbols in print advertisements of these luxury brands from the perspective of Semiotic, to explore the reasons of success of print advertisements of luxury brands and connotation meanings behind extension meanings from these image symbols. It is necessary to master some features of symbols well during advertisements design, sophisticated symbol design during advertisements design can improve texture and level of advertisements as well as spread messages accurately, achieving the unity of beauty and practicality.
\end{abstract}

Keywords: semiotics, advertisement, signs

\section{Introduction}

Nowadays, as a part of our life, advertisements appear anywhere and anytime. Analysing them has become an indispensable activity in our society. Semiotics is the key to advertisement decoding. Bignell (1997) claimed that Semiotics refers to the study of how signs communicate meanings. Semiotics is a type of signs' study. In this essay, I will focus on semiotics in our contemporary society, and then will briefly start with outlining the theory of semiotics. This section will be followed by an analysis of two perfume advertisements based on the theory of semiotics. After that, I will go on to discuss how the advertisement produces meanings and attracts the viewers. In the final section, it is claimed that semiotics is an extremely useful tool of analysing advertisements.

\subsection{Theory of Semiotics}

In contemporary society, semiotics is an important tool of analysing and decoding advertisements. Most of the advertising agencies adopt semiotic methods to design advertisements. Besides, semiology and semiotics have the same meaning. As great pioneers of semiotics, Ferdinand de Saussure in Switzerland and Charles Peirce in the USA have many important theories in the semiotics study area.

An indispensable theory from Saussure shows that the sign consists of two parts. The first part of the sign is the signified which is a concept or a meaning. The second part of the sign is the signifier which as an image or a word, expresses the signified. The relationship between the signifier and the signified is usually arbitrary.

Danesi (1999:23) argued that the crux of semiotic analysis is, in effect, to unravel what something means, or more accurately, represents. There are two types of representation: denotation and connotation. Barnard (2001:149) thought that denotation is a kind of meaning when shapes, lines, colours and textures are understood as representing things in the world. Connotation is often explained as the thoughts, feelings and associations that accompany one's perception of an example of visual culture. When you watch the advertisements, there are some kinds of thoughts that come into your mind.

After Saussure, Charles Peirce created three different types of signs: iconic signs, the index and symbols. An iconic sign bears a resemblance to the one which represents and can be an image or graph (Lacey, 1998:66). Indexical signs are often used in advertising. In an indexical sign, the relation between the sign and the object is an existential or caused relation. In a symbol, the sign and the object are connected or related by convention. (Barnard, 2001:148) 
According to Suussure, Roland Barthes (1973) created the myth that is a system of communication and a message. There is an important theory created by Barthes, who (1973) argued that the myth is a double system. The sign can become the signifier of a second-order system of signification for creating a connotation and a myth. In other words, a sign in the first system becomes a mere signifier in the second. Berger (2004:107) argued that semiotics is defined as the science of signs to deliver some kinds of messages and to generate some kinds of meanings. Semiotics plays a vital role in the myth. We can use semiotics methods to analyse the myth. Myers (1998:18) claimed that semiotics is the academic discipline that deals with the ways that signs take on meanings, and treats the myth as one element in the social sign system it examines.

\section{Analysis of Two Women Luxury Perfume Advertisements}

In my paper, I choose two feminine fragrance advertisements which are Dior J'adore and Burberry London, the analysis based on semiotics theory.

\subsection{Dior J'adore}

The first advertisement I choose concerns Christin Dior perfume. Christin Dior is also called CD or Dior. As a classical brand of France, Dior perfume is popular with young and middle-aged women. J'adore as a French word means adoration or my adoration in English.

In this advertisement, we can see that there are several elements which are an attractive woman, a bottle of J'adore, two characters, a pair of luxury earrings and background. There are three main colours, namely gold, black and white. All of them are signs and denotation. These elements also manifest the concept of luxury, which is a connotation.

The golden-haired beauty in a sexy evening was appearing in the scene enchantingly, and the evening foiled her excellent stature. She wore a pair of shining diamond danglers, and was making up in front of the dresser in order to attend an evening party. She was looking at her appearance in front of the mirror and showing self-confidence. It's out of question that she would be the focus in the evening. The whole hue of the advertisement is mainly golden, and the shadow part in the picture can set off the golden hue better. Lacey (1998:38) believed that as a code, colour takes its cue from social codes, and is used to attract the audience's attention. Gold can give people a deep impression. At the right corner of the picture, a shining bottle of J'adore is reflected by the slippery table board. Like a brilliant gemstone, J'adore is very luxurious and dazzling on seeing it at my first sight. The bottle of J'adore is featured with a pure and eternal style. The design of the bottle signifies luxury, wealth and art. It is classic, elegant and attractive. The long bottleneck seems nobler with a golden scarf circling around it. The golden body is vitreous and smooth without any decoration. Beside the perfume, there is a character 'J'adore'. Bignall (1997:34) said that the name of the perfume becomes a linguistic sign that seems to connote feminine beauty. J'adore has become a sign, which means beauty.

The beauty in the image is Charlize Theron, who was born in South Africa and is 28 years old. She is very young with a beautiful face and a nice figure. She is also named "Venus", and was already a fan of J'adore. At the same time, she is a glamour icon of Hollywood cinema. She was selected as one of top 50 beautiful women all over the world by PEOPLE magazine, in 2002. In 2004, she had perfect performance in her film Monster. She gave audiences a deep impression in this film, since she already won an Oscar, a Golden Globe and a Vanguard Award. She is a beautiful female, who is very strong-willed and set out to challenge herself. The advertisement embodies her majestic femininity and her eternal beauty. Charlize Theron becomes the symbol of this fragrance.

In the advertisement, a charming lady and a bottle of J'adore signify the mental concept of Charlize Theron and perfume respectively, which is the first level of signification or the denotative level. The level of denotation expresses the basic meaning of the sign. However, the signs of Charlize Theron and perfume can signify the mental concept of beauty and luxury.

We can use Peirce's theory to analyse the advertisement, and the images are iconic signs. Bignall (1997:35) argued that the iconic sign of the model can signify beauty. Charlize Theron shows beauty and richness in the advertisement. The perfume and beauty is the indexical sign, while perfume can be related to a beautiful woman. J'adore perfume symbolises attraction and luxury. People use signs to describe and interpret the world. Bignall claimed (1997:32) that the signs in ads have connotations and meanings, which come from our culture. For example, the main colour in the advertisement is gold. In our culture, gold means nobleness and luxury, which are matching the theme of the advertisement.

In this spring, Dior redefines luxury and launches a limited edition of J'adore. J'adore is very similar to classical J'adore and retains the original fragrance. However, different from classical J'adore, there are slim golden slices treated by gilding in each new J'adore. By gently shaking the perfume bottle, you will find the subtle sparkles. 
When the perfume is sprayed on your skin, it will make every inch of your skin emit fragrance and sparkle with golden extravagant light. The charming fragrance will impress you uniquely and memorably. Both the construction of golden rhythm and the glinting luxurious golden decorations focus on the same topic-the true beauty is the one that exists around us. J'adore, which is covered in the golden rays of light, is aloof and proud, but never apathetic. If you want to be the brilliant queen of this quarter, you shall use it that can give you irresistible beauty. You can't wrestle with the temptations of J'adore.

Bignall (1997) described that buying and using an attainable thing gives access to a social meaning. For example, if people buy a bottle of J'adore, the perfume will give them feminine beauty. J'adore becomes a sign of feminine beauty, so that buying the product for ourselves seems to share the meaning of feminine beauty.

\subsection{Burberry London}

The second perfume advertisement involves Burberry found in 1856 by 21-year-old Thomas Burberry. The brand also enjoys a history of 150 years up to now. The classical Burberry Check which is crossly composed of red, black, camel and white. The Burberry Check was registered as Burberry's trademark. It has come to be synonymous with Burberry.

Burberry is a luxury brand with a distinctive British sensibility, strong international recognition and differentiating brand values that resonate across a multi-generational and dual-gender audience. Since its foundation in England in 1856, Burberry has been synonymous with quality, innovation and style. This brand has intertwined with daily life in Britain, and represents the concise and rigorous features of Britain.

Burberry is launching a new kind of perfume called London. This advertisement is very romantic. The images are presented by personal memories. The advertisement consists of five parts, namely an opening photograph album, several black-and-white photos, some characters, a logo of Burberry and the classical check pattern of Burberry. Every element in the advertisement is a signifier. Goldman (1992:5) argued that as a system of signification, advertisements compose the connections between the meanings of products and images. Every picture in the advertisement is close to the life, and tells her life and her love stories. There are some important photos concerning her sweet memory, and they recorded many dribs and drabs of her life, which give her aftertaste a lot. They left their footprints everywhere in London. All these extraordinarily famous scenes such as London Eye and Big Ben belong to London. The Image of Victoria Embankment at twilight is extremely romantic. A nostalgic feeling arises from black-and-white photos. This advertisement is in the style of London. From the buildings, the clothes, the people and the red telephone booth in the picture, we can easily infer that it is in London. These just match the name of the perfume- Burberry London, which is designed in a simple but nostalgic way and is also fit for London, an old and tasteful city. In the picture in the middle, she closes her eyes and enjoys everything around her: flowers, fresh air and sunshine.The blessedness and happiness fall on her face. On the other side of this page, there is a bottle of Burberry London in the middle. Around it, there are some old photos. In this case, it can be seen that Burberry London can become a sweet and unforgettable memory in your life. The objects and people in the advertisement are signs. There are some characters on the photos, such as the name and the place. All of them can match the name of the perfume-London. Rachel Weisz born in London is the 'face of London'. The picture of the model is also a sign, which has connotations like youth, femininity and charm. Burberry London is the quintessence of modern young women, which means optimistic, glamorous and intelligent features. They bring information to people; the perfume is different from others, and is featured with a kind of London style, which symbolises London.

The advertising word of Burberry London is 'a new fragrance of women', which is related to the advertisement and the product. The language is a sign, and brings meaning to people. These words point out the theme of the product and present a new appearance of you to others. The advertisement brings fresh air to people just like the unique smell this perfume brings to you, and it makes you more special among people.

As for this advertisement, we can also use Barthes' theory that is 'the myth is a double system' for analysis. In the advertisement, pictures and Burberry London signify the mental concept of photos and the perfume respectively. In the first level, they become signs, but the sign photos and perfume will signify the mental concept of romance and reminiscence. Similar to the first advertisement, the images are iconic signs in the advertisement. The photos and memory are indexical signs. The perfume symbolises reminiscence and classicality. Williamson (1978:11) argued that the advertisement is one of the most important cultural factors that mould and reflect our life today. In the advertisement, the photos reflect her daily life, which means that Burberry London is very close to life. 


\section{How Advertisement Produces Meanings and Attracts the Viewer}

Williamson (1978) argued that one of the most influential ideological forms in contemporary capitalist societies is advertising. The two perfume advertisements reflect the female's status in the society. Wolf (1991:10) claimed that more women have more money, power, scope and legal recognition than we have ever had before. Women have begun to change their roles in the society, and they've received their rises in status. They are not just housewives any more. Instead, they are able to make themselves up very well and make themselves more attractive.

Woodward (1997) held that the identity gives us an idea of who we are and how we relate to others and to the world where we live. Williamson claimed that people can identify themselves with their consumption (1978:13), their car and their perfume, which become the indexical signs of their social identity. Products become signs with a certain social value. Dior J'adore and Burberry London symbolise two kinds of groups in our society. They have different definitions of beauty. People who use Dior J'adore like luxurious things in their daily life, while those people who prefer Burberry London like reminiscence and London style. We can identify them by these two kinds of perfume.

From these two advertisements, we can know that most of the leading actors in the perfume advertisements are the popular stars these days. They are sexy and charming with great forces and persuasion. The most impotent aim of advertising is persuading people to buy their products. The popular star is an indispensable element in advertising. Advertisements choose popular stars to symbolise beauty and success, and make people envy and then buy the products. Advertising is a central component of consumer societies. Sturken (2001:189) pointed out that advertising often presents an image of things to be desired, people to be envied, and life as it "should be". Advertisements show social values and ideologies about what the good life is. Advertisements are creating commodity signs by using photos to construct their messages. All the advertisements tell consumers that their products will change people's life and make the life better if people buy their products. Advertising promises to improve our life, and makes people envy and wish to emulate. Sturken (2001:206) argued that advertising uses particular codes and conventions to convey messages quickly and succinctly to viewers. The world created by advertisements can also appear to be precious, artistic, and valuable. Advertising gives value to products through semiotics. A product can take on any meaning, while semiotics gives meaning to products. When we analyse advertisements based on semiotics, we can understand the meaning of it. Most people buy products, such as perfume for the meaning presented by advertisements, which were a way of selling products only in the past, while now have become indispensable ways of daily communication in the new commodity culture of the 21 st century. In a word, it is an important activity in our daily life.

In my opinion, semiotics is a useful tool of analysing advertisement in contemporary society. Every advertisement includes signs. Bignell claimed that semiotics can provide a framework for precise discussion of how these signs work (1997:26). Semiotics means 'the study of signs'. Lacey (1998) argued that advertisements saturate our social lives that can be reflected in advertisements. According to Storey's discussion, goods can be considered as a symbolic means of communicating with others (1999:28). Advertisements give meanings to the social world, such as products, buyers of products and readers of ads. The advertisement is, in fact, a way of communication. Also, the way of signs and the principle of signs are used. The accuracy in sign use is therefore important for fulfilling the purpose of transmitting the information. You can never fail to notice signs in an advertisement. Rose (2001) claimed that images are interpreted in close relation to semiological theory and semiotics is centrally concerned with the social effects of meanings. Semiotics can help people decode the advertisement. People understand the meaning of advertisements through semiotics. If we do not use semiotics, it is difficult to decode advertisements. We know the structures of advertisements from semiotics. The sign is related to the object in our daily life, so that we can know the meaning of advertisements by signs. People can understand advertisements easier and clearer through semiotics.

\section{Conclusion}

In conclusion, the advertisement is extremely close to our daily life. The content and meanings of advertisements are from our life. We decode advertisements through semiotics. There are three important people in the semiotics study area. The first one is Saussure, who though the sign is composed of the signifier and the signified. The second person is Peirce, who divides signs into three types, namely iconic signs, the index and symbols. The last one is Barthes, who argued that the myth is a double system. These theories are extremely important and useful for helping us analyse advertisements. In this case, I use their theories to analyse two advertisements, Dior J'adore and Burberry London, and can understand the meanings and structures of the advertisements by the theory of semiotics. Advertisements produce meanings though signs, and prefer to select some popular stars or 
successful people, who can persuade people to buy products. Advertisements also promise people that when they use the products, the life will be better. As people envy the stuff of advertisements, and they want to become better people or lead a good life, they will buy the products. In my opinion, semiotics is very useful for analysing advertisements in our life. Then, the meaning of advertisements can be understood through semiotics that has provided us with a good platform for advertisement analysis. In this case, we could find the traces of our life in the advertisement, and know the relationship between the advertisement and us. Therefore, semiotics is an indispensable theory of decoding images in modern times.

\section{References}

Barnard, M. (2001). Approaches to Understanding Visual Culture. New York. https://doi.org/10.1007/978-1-137-11046-6

Barthes, R. (1973). Mythologies. London: Paladin.

Berger, A. A. (2004). Ads, Fads, and Consumer Culture. Lanham,Md.: Rowman \& Littlefield.

Bignell, J. (1997). Media Semiotics: an introduction. New York: Manchester University Press.

Danesi, M. (1999). Of cigarettes, High Heels, and Other Interesting Things: An Introduction to Semiotics. New York: St. Martin's Press.

Goldman, R. (1992). Reading Ads Socially. London; New York: Routledge.

Lacey, N. (1998). Image and Representation. Macmillan. https://doi.org/10.1007/978-1-349-26712-5

Myers, G. (1998). Ad Worlds: brands, media, audiences. New York: Arnold.

Rose, G. (2001). Visual Methodologies: An Introduction to the Interpretation of Visual methodologies. London; Thousand Oaks, Calif.: Sage.

Storey, J. (1999). Cultural Consumption and Everyday Life. London: Arnold; New York: Co-published in the U.S.A. by Oxford University Press.

Sturken, M. (2001). Practices of Looking: An Introduction to Visual Culture. Oxford; New York: Oxford University Press.

Williamson, J. (1978). Decoding Advertisements: Ideology and Meaning in Advertising. London: Boyars: Distributed by Calder and Boyars.

Wolf, N. (1991). The Beauty Myth: How Images of Beauty Are Used Against Women. London: Vintage.

Woodward, K. (1997). Identity and Difference. London; Thousand Oaks, Calif.: Sage in association with the Open University.

\section{Advertisements}

Dior J'adore is from GLAMOUR APRIL 2006.

Burberry London is from GLAMOUR APRIL 2006.

\section{Copyrights}

Copyright for this article is retained by the author(s), with first publication rights granted to the journal.

This is an open-access article distributed under the terms and conditions of the Creative Commons Attribution license (http://creativecommons.org/licenses/by/4.0/). 